\title{
Sájer István
}

\section{A zöldség-gyümölcs ágazat külkereskedelmének jövőképe}

István Sájer: Foreign trade possibilities of the Fruit - Vegetable sector in the future

\begin{abstract}
Hungary can be considered as a small, open economy, therefore the domestic market doesn't provide enough possibility to sell the grown and produced agricultural products, exportation is vital. In the year of 2010 Hungary had trading activity on the field of agricultural products with 151 countries, which has grown to 164 countries by 2013. According to the Strategy of the FruitVegetable Sector the production target is 3,5 million tons for the year of 2020. This target has already been reached in 1990, since then the average production is $2-2,5$ million tons yearly. We can increase our foreign trade only if the properly classified, carefully packed products can be delivered in the requested quality on the contracted time. Perhaps this is the most sensitive territory where the Hungarian producers are falling back from the international trends. Due to the lack of cash and capital the technological and technical development of the is missing, the trade channels are getting more and more narrow, which will lead to loosing of the market. Nowadays the main problem of the Hungarian Vegetable-Fruit sector is the diminishing quantity of marketable goods, despite of the fact, that the sector could remain a net exporter. The presence of the black market is overwhelming in Hungary which makes the sector vulnerable and hard to regulate. Despite of several good examples and successful enterprises it is still true that the majority of the producers are lacking the needed technological, marketing, management and trade knowledge. They insist on using their obsolete methods, and not willing to learn and change. There is a problem in the forecast of the expected yield. The Vegetable-Fruit sector is the most export driven part of the Hungarian agricultural sector as it is selling more than the $50 \%$ of all production abroad. In order to be sustain this share it would be fruitable to have a more favorable tax policy and the revision, cancellation of the "Primary producer" system. In each case the main problem is that there is no common base and trust between the trader, producer and management. This is why it might happen that a member of the TÉSZ is willing to sell his product outside the system, because this way he thinks to have safe income. As the organization doesn't have a safe base of products for sale they can not develop the market and if they have no safe market, due to the missing trust there will be no safe base of products for sale, and the circle is closed and the whole problem starts again.
\end{abstract}

Key words: Strategy of the Vegetable - Fruit Sector - 3,5 million tons of production, 100.000 new workplaces in the sector, keeping up the export position of the sector, fight against black trade, Increase of the importance of the "TÉSZ", Increase the marketing activities

\section{ÖSSZEFOGLALÓ}

Hazánk a kis, nyitott gazdaságok közé sorolható, így a kis belső piac nem elegendő a megtermelt mezőgazdasági termékek értékesítéséhez, létfontosságú az export.
Magyarország 2010-ben összesen 151 országgal, míg 2013-ban 164 országgal kereskedett mezőgazdasági eredetű árukkal. A Zöldség - Gyümölcs Ágazati Stratégiában megfogalmazott 3,5 millió tonnás termelési mennyiség elérése a cél 2020-ra. A megcélzott 
mennyiséget 1990-ben értük el, azóta is az évi termelési mennyiségek átlagosan csak a 2,0 2,5 millió tonnás mennyiséget érik el. A külkereskedelmünket csak úgy tudjuk bővíteni, ha a megtermelt termékeink megfelelöen osztályozzuk, gondosan csomagoljuk, egyöntetű, a vevői elvárásoknak megfelelő minőségben és a szállítási határidők pontos betartásával érkeznek meg. Talán sehol annyira nem mutatható ki leszakadásunk a nemzetközi tendenciáktól, mint éppen ezen a területen. A pénzhiány és tőkeszegénység miatt elmaradt az ágazat technikai és technológiai fejlesztése, beszúkültek a kereskedelmi csatornák, ami piacvesztéshez vezetett. Jelenleg a magyar zöldség-gyümölcs ágazat legfőbb problémáját az áruhiány jelenti, annak ellenére, hogy még mindig megőrizte nettó exportőr státuszát. Hazánkban, a zöldség-gyümölcs ágazatban óriási a feketekereskedelem jelenléte, amely által az egész ágazat szabályozhatatlanná és kiszolgáltatottá válik. Számos jó példa és sikeres üzem mellett is igaz, hogy a termelők zömének hiányosak a technológiai-, menedzsment- és marketingismeretei. Ragaszkodnak az elavult módszerekhez, változtatni, tanulni nemigen hajlandók. Gond van minden egyes előre jelzett mennyiséggel, legyen ez akár kisebb-, vagy nagyobb termésbecslés. A zöldséggyümölcságazat az összes mezőgazdaság ágazat közül rendre az egyik legnagyobb exportárbevételt produkálja azzal, hogy termelésének 50\%-át külföldön értékesíti.

Ennek a fenntartásához kedvezőbb adópolitikára és az őstermelői rendszer felülvizsgálatára, megszüntetésére lenne szükség. Minden esetben az alapprobléma az, hogy nincs érdekazonosság és bizalom a kereskedő, a termelő és a menedzsment között. Ezért - is - van az, hogy a tag sokszor a TÉSZen kívül adja el termését, mert így legalább biztos pénzt lát. Márpedig, amíg a szervezetnek nincs biztos árualapja, addig nem tud piacot építeni, amíg pedig nincs biztos piaca, addig bizalom hiányában nem lesz biztos árualapja, és a kör bezárult, illetve kezdődik elölről.
Kulcsszavak: zöldség - Gyümölcs Ágazati Stratégia- 3,5 millió tonnás termelés, 100 ezer új munkahely az ágazatban, az export piaci pozíciójának a megtartása, a feketekereskedelem visszaszorítása, a TÉSZ-ek szerepének növelése, a marketingtevékenység fokozása

A konferencia jelmondatának megfelelően „Mond el a múltat, diagnosztizáld a jelent, jósold meg a jövőt"- foglalom össze az ágazat jövőképét, beépítve azon személyes harminc éves tapasztalatomat, melyet eddig az ágazat külkereskedelmében szereztem. Tapasztalataim szerint a zöldség-gyümölcs ágazat külkereskedelmével foglalkozó szakirodalom nem teljes mélységben, nem gyakorlati megközelítésben foglalkozik a témával. Éppen ezért a zöldség-gyümölcs külkereskedelem sajátosságait, annak gyakorlati tapasztalatait kívánom kiemelni. Bízom benne, hogy gyakorlati tapasztalataim megosztásával elő tudom segíteni az ágazat külkereskedelmének a fejlesztését, az ágazat további fejlődését. A vad és termesztett bodzával is érdemes lenne külön foglalkozni, (sajnos a terjedelmi lehetőségek ezt nem teszik lehetővé) mivel a világ termeléséből hazánk 15-18 \%-ban részesedik, és ez a részesedés még növelhető a természetes színanyagok felhasználásának az elterjedésével.

Magyarország adottságai kedvezőek a mezőgazdasági termeléshez, így hazánk nemzetgazdaságában tradicionálisan fontos szerepet tölt be. Magyarország természeti adottságai a mezőgazdasági múvelés szempontjából az átlagosnál kedvezőbbek, talajaink termékenyek, éghajlatunkban sok a napsütéses órák száma, ami jó minőségú és megfelelő mennyiségú terméseredmények elérését teszi lehetővé. Ennek révén évezredes múltra visszatekintő agrárkultúra alakult ki. Magyarország az európai országok között kitúnik a szántó és a mezőgazdasági terület magas arányával.

$\mathrm{Az}$ átalakulás kezdetén, 1989-ben a mezőgazdaság részesedése a GDP előálításból még 13,7 százalék volt, 1995-ben 7,2 \%, 2008-ra 3,4 százalékra mérséklődött, míg 2010-re 
tovább mérséklődött és csak 3,0 százalék volt. A mélypont 2009. évben volt, mikor is a részarány mindössze 2,5 \%. 2012-ben a GDP előállításából 3,2 \%-ban részesedett. (Mezőgazdaság 2012.
KSH 2013.április) 2013-ban viszont a mezőgazdaság részaránya ismét elérte a 4 \%-ot a GDP előállításában.

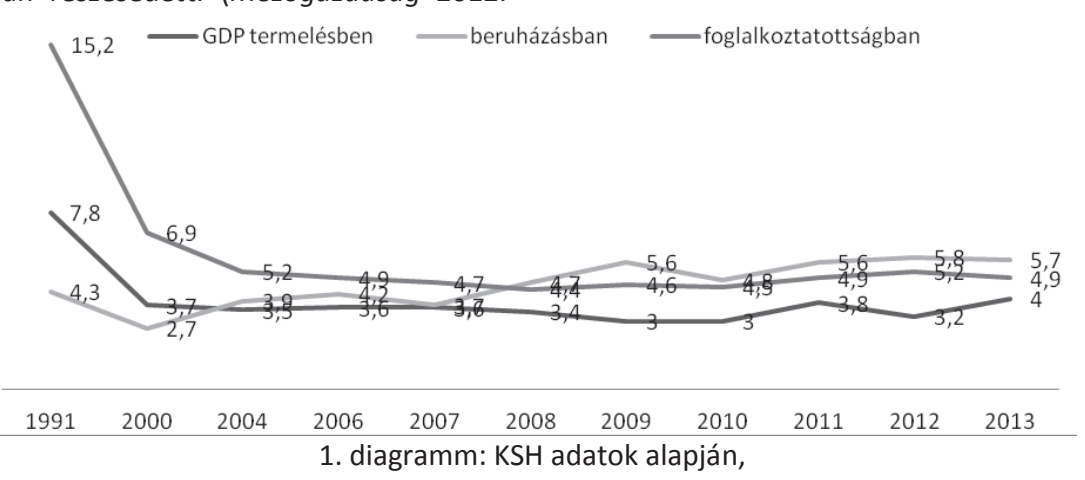

1. diagramm: KSH adatok alapján,

saját szerkesztés

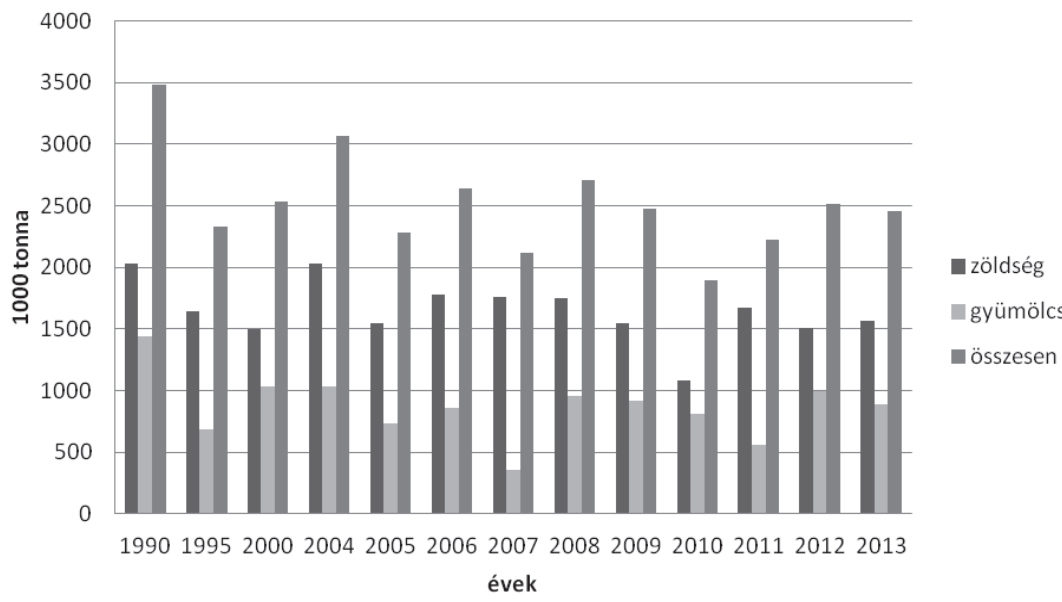

1. grafikon: Zöldség-gyümölcs termelés

FruitVeb adatok alapján saját szerkesztés)

A fenti táblázatból jól kiolvasható, hogy a Zöldség-gyümölcs Ágazati Stratégiában megfogalmazott 3,5 millió tonnás zöldséggyümölcstermelésünket 1990-ben értük el, azóta sem, sajnos. 2004-ben ugyan még átléptük a 3 millió tonnás (3,069 millió tonna) termésmennyiséget, de a következő években csak a 2,0 - 2,5 millió tonnás termékmennyiséget tudjuk előállítani. Az okok összetettek, melyekre a későbbiekben térek ki. Hazánk a kis, nyitott gazdaságok közé sorolható, így a kis belső piac nem elegendő a megtermelt mezőgazdasági termékek értékesítéséhez, létfontosságú az export. Magyarország 2010-ben összesen 151 országgal kereskedett mezőgazdasági eredetú árukkal. Az export közel $81 \%$-át 14 ország, közöttük 11 EUtagország fogadta be. Az import több mint $82 \%$ át 10 EU-tagország szállította, és az összes behozatal közel 90\%-a érkezik hazánkba az unióból. (Mezőgazdaság 2010. KSH) 2012-ben az országok száma 148. Ezek közül 106 országgal kétirányú kapcsolatban bonyolítottuk le a forgalom döntő hányadát, további 42 
országba csak exportáltunk, 15 országból csak importáltunk. 2012-ben a zöldség ágazat exportjának a 86,08 \%-a irányult az EU tagországokba, míg a gyümölcs részaránya az ágazat exportjából 90,25 \% volt. Az EU-ból érkező import részaránya 2012-ben a zöldség ágazatnál 81,92 \%-ot képviselt, a gyümölcsnél ez a részarány $88,72 \%$ volt. (Mezőgazdaság 2012. KSH) 2013-ban az országok száma elérte a 164-et, de a forgalom értéke csak 85 ország esetében érte el az 1 millió eurót.

A zöldség-gyümölcs ágazat elsődleges termékkibocsátása a mezőgazdasági termékek 12.2 \%-át tette ki, melyen belül a zöldség: gyümölcs arány 70:30 \%-ot mutatott 2013-ban. Legfontosabb kereskedelmi partnereink köre nem változott 2012-hez képest. Németország, Románia, Szlovákia, Ausztria, Olaszország, Hollandia, Lengyelország, Csehország, Franciaország és Nagy Britannia részesedése a magyar agrár-külkereskedelmi forgalomból 75 százalék volt. Az agrár-külkereskedelem döntő részét 2013-ban is az Európai Unió tagállamaival bonyolítottuk. Az EU az exportértékből 86 százalékkal, az importértékből 93 százalékkal részesedett. ( $A z$ élelmiszergazdaság külkereskedelme 2013)

A világ agrár-külkereskedelmének alakulása hazánk számára exogén (külső) tényezőnek tekinthető, mivel jelenleg Magyarország részesedése a világ agrárexportjából 1 százalék alatti. A globalizáció nyitott gazdaságunk számára számos előnye mellett különböző hátrányokkal járhat, melyeket enyhíthet a gazdasági integrációkban való részvételünk.

2013-ban a magyar agrárexport 8,093 milliárd eurót tett ki, 18 millió euróval, 0,2 százalékkal haladta meg a 2012-es szintet. A magyar agrárexport értéke 2010-ben 6 milliárd euró alatt maradt. Az agrár-külkereskedelem 2013ban 3,6 milliárd eurós aktívumot ért el, erre sem volt még példa. A mezőgazdasági- és élelmiszeripari termékek részesedése a teljes nemzetgazdasági exportból 2012-ben 10,1, 2013-ban 9,9 százalék volt, az importból pedig 2012-ben 6,1, 2013-ban 6,0 százalék. Az agrárexport aránya 2012-ben és 2013-ban igen magas volt, részesedése utoljára 1998-ban haladta meg a 10 százalékot, azóta 6-8 százalék között ingadozott. Ez a nemzetgazdaság 2013. évi külkereskedelmi aktívumának 50 százalékát tette ki. A több éves átlagnak megfelelő évi 800-850 ezer tonna teljes zöldség- és gyümölcsexportot a következő néhány év alatt 1,2 millió tonnára lehet emelni. A kertészetben 2013. évben a 2012. évihez hasonló eredmény született. A 2000 milliárd forintos mezőgazdasági elsődleges termelési értéken belül a kertészet jelenleg mintegy 16-17\%-ot képvisel, ami 330-340 milliárd forintos elsődleges termelési értéket jelent. A kertészeti ágazaton belül a legnagyobb értéket (62\%) a zöldség-gyümölcs ágazat képviseli, rajta kívül 11\%-a dísznövény, $8 \%$ a burgonya, $7 \%$ a szőlő, $9 \%$ a bor és $3 \%$ az egyéb (gyógynövény, városi kertészet, stb.). (FruitVeb évértékeló)

A kertészeti termelés szempontjából fontos szakmai esemény a Vidékfejlesztési Minisztérium által meghirdetett Nemzeti Zöldség - Gyümölcs Stratégia, amely 2020-ig kijelöli azokat az irányvonalakat, melyek várhatóan elérhetóvé teszik az 1 millió tonna plusz zöldség-gyümölcs előállítását és az ehhez kapcsolódó 100 ezer új munkahely létrehozását.

\section{PROBLÉMÁK ÉS JAVASLATOK}

1., A Magyar Kereskedelmi és Ipar Kamara 1903-ban kiadott évkönyve a magyar zöldségés gyümölcsfélék exportpiaci helyzetéről a következőket írta:

„A kertészeti termékeink egyedi íze, zamata megkülönböztetett kedveltséget biztosítanak nekik, és ha kivitelünk jövedelmezősége még nem felel meg a várakozásoknak, ezt annak kell tulajdonítani, hogy gyümölcs és konyhakerti növényeink szedése, válogatása és csomagolása még nem felel meg a nyugati fogyasztói piacok kívánalmainak. Pedig kielégítő árakat csak úgy érhetünk el, az idegen versenyt úgy győzhetjük le, ha jól osztályozott, gondosan csomagolt árunk kifogástalan, egyöntetű minőségben és a szállítási határidők pontos betartásával érkeznek meg." (Lakner Zoltán - Sass Pál) $\mathrm{Az}$ elmúlt évtizedekben nem volt olyan gazdaságstratégiai dokumentum, amely a fenti 
problémákat ne fogalmazta volna meg. Sajnos a jelenlegi helyzet is ezt mutatja.

A fejlett országok kertészeti termesztésében a termékek versenyképességében, egyre nagyobb szerepet kap a megfelelő csomagolás, áruvá készítés. Talán sehol annyira nem mutatható ki leszakadásunk a nemzetközi tendenciáktól, mint éppen ezen a területen. Amíg a fejlett országokban mikroprocesszoros vezérlésú permetező rendszerekkel, csepegtetó öntözéssel, különleges válogató berendezésekkel termesztik és készítik áruvá a gyümölcsöt, addig hazai viszonyaink között az öntözés egyre kevesebb figyelmet kap, a növényvédelem gyakran esetleges és az áruvá készítés, - ha egyáltalán történik ilyen - nem sokban különbözik a fél évszázaddal ezelőtti módszereinktől.

A lemaradásunkat be lehetne hozni rövid időn belül, ha a rendelkezésre álló Európai Uniós támogatásokat erre a területre „összpontosítanánk”. A támogatások felhasználása ugyan megtörténik, de a TÉSZ-ek kapják a magasabb (70-75 \%-os) támogatási intenzitásokat. $\mathrm{Ki}$ is használják, de árualap hiányában nem hasznosulnak ezek a beruházások. A nagykereskedők, exportőrök viszont kisebb (40 - $60 \%)$ intenzitású támogatásokat kapnak, vagy valamilyen kírási kitétel miatt kimaradnak a lehetőségekből. Megfontolandó lenne, ha a pályázatokat az export növelése érdekében írnák ki a TÉSZekhez hasonló feltételek mellett. A TÉSZ-ek fejlesztése, az összefogás elősegítése az alapvető cél, amely helyes is, de mint ahogy látni fogjuk a példákon, nem hasznosul megfelelően a beruházásokra fordított összeg.

2., A versenyképesség egyik kulcsterülete a zöldség-gyümölcs ágazatban a minőség. Ahogy a németek mondják „Preis spielt keine rolle, nur Qualität” Az ár nem játszik szerepet, csak a minőség. Természetesen, ha a minőség megfelel az elvárásoknak, akkor igen is a minőséghez kapcsolható árnak nagy szerepe van. $A z$ ezen a területen múködő vállalkozásoknak csak egy alacsony hányada felel meg az EU élelmiszer-biztonsági, higiéniai, környezetvédelmi és minőségi előírásainak, ami akadályozza a piac hatékony múködését. Gondot okoz az infrastruktúra elmaradott állapota, a logisztikai rendszer fejletlensége, a gazdaságban jelen lévő bizonytalanság és az információhiány. Az információ alapvető erőforrás a modern gazdaságban, az információhoz való hozzájutás az egyik meghatározó tényezője a hatékonyan múködő piac kialakulásának. Sajnos Magyarországon a konkurencia nem áll szóban egymással, ellenséget látnak a másikban és nem ellenfelet. A lejáratás minden eszközét felhasználják a másik ellen, függetlenül a valóságtól. Nem látják be azt a mondást, hogy „a konkurenciáról jót vagy semmit, ha jót nem tudok, vagy nem akarok mondani, akkor inkább hallgassak". A Lajtán túli országokban a konkurencia "beszél” egymással, információkat cserélnek és ezen információk birtokában ülnek le tárgyalni a magyar exportőrökkel, így kedvezőbb pozícióban várják a szerződéses tárgyalásokat. Magyarországon is csak megbízható információk és statisztika birtokában lehet az exportban is versenyesélyünk.

A legtöbb vállalat, sok esetben saját sikertelenségéből okulva, ráébred arra, hogy mennyire fontos megismerni azoknak az országoknak a szokásait, viselkedésformáit, tárgyalási stílusát, üzleti kommunikációs sajátosságait, és nem utolsó sorban legalább alapszinten a nyelvét, amelyekkel üzleti tevékenységet kíván folytatni. Azt is számos esetben tapasztalják, hogy komoly üzleteket veszíthetnek el, ha nem fordítanak kellő figyelmet a kulturális különbségekre, és más kultúrák érzékenységét, vagy társadalmi, illetve üzleti gyakorlati normáit megsértik. (Falkné $D$. Bánó Klára)

3., A rendszerváltás óta a zöldség-gyümölcs ágazat termelése a korábbi 3,5-3,8 millió tonnáról fokozatosan visszaesett a jelenlegi 2,5 millió tonna körüli szintre. A visszaesés fö oka, hogy a tulajdoni szerkezetben történt változások ellenére nem alakultak ki versenyképes termelési struktúrák. A pénzhiány és tőkeszegénység miatt elmaradt az ágazat technikai és technológiai fejlesztése, beszúkültek a kereskedelmi csatornák, ami 
piacvesztéshez vezetett. Jelenleg a magyar zöldség-gyümölcs ágazat legfőbb problémáját az áruhiány jelenti, annak ellenére, hogy még mindig megőrizte nettó exportőr státuszát. A friss termékek iránti fogyasztási szokások új, célirányos fejlesztési programokat igényelnek. A friss termelés mellett nagy visszaesés következett be az ipari nyersanyagtermelés területén is, a feldolgozóipar termékstruktúrája rendkívül beszúkült, csak néhány termékre (csemegekukorica, zöldborsó, meggybefőtt, almasűrítmény) korlátozódik. A csökkenó termékmennyiség mellett a kereskedelmi integrációs tevékenységek (TÉSZ-ek) fejlődése is ellentmondásossá vált, s így a meglévő bel- és külpiacainkat nem tudjuk kiaknázni. Hazánkban, a zöldség-gyümölcs ágazatban óriási a feketekereskedelem jelenléte, amely által az egész ágazat szabályozhatatlanná és kiszolgáltatottá válik. Alapvető probléma, hogy a termelői adózási, foglalkoztatási és finanszírozási okokból nem érdekelt abban, hogy fejlessze a termelését és átláthatóan gazdálkodjon. (Fruitveb, 2012; Popp et al.,2009b).

A szétaprózott termesztést és árukoncentráció hiányát a nagy mennyiségú, egységes árualapokkal és jól körülhatárolható termelői körzetekkel lehetne megoldani. A termelők között nagy méret és jövedelmezőségi különbségek vannak. A jól körülhatárolható termelői körzetekkel erősíteni tudnánk a hazai árukínálatot és növelhető lenne a termelői szervezettség. Sajnos ez utóbbin a rossz beidegződés, a birtokméretek heterogén volta, a termelők hozzáállása a szervezetekhez, az értékesítés szervezetlensége, mind nehezítik a megvalósítást. A TÉSZ-ek alacsony vonzóképessége is a termelői hozzáállásból fakad. Más a termelői érdek egy kisebb termelőnek, mint a TÉSZ esetlegesen független vezetésének (sajnos sokszor a nagyobb termelők alkotják a vezetést és nem „független” vezetés). Alkupozíciót csak megfelelő egységes árualappal lehet elérni úgy az exportban, mint a hazai piacon. Ha én csak ajánlani tudok napi 15 kamion bodza pulpot (darálmány), azzal nem tudok piacra kerülni. Azt meg kell mutatnom, hogy le is tudom szállítani. Csak így lehetek komoly szereplője a piacnak. A TÉSZ-ek sokszor azért kerülnek „kellemetlen” helyzetbe, mert a termelők 1-2 forintos különbségért, esetleg „papír” nélkül eladják az árujukat a neppereknek és valamilyen kifogással élnek a TÉSZ irányában. Viszont, ha több a termés, esetleg nehezen értékesíthető is, rögtön a TÉSZhez viszik az árujukat, hogy adja el, hisz azért hozták létre. El kell mondani az igazsághoz azt is, hogy Magyarországon hiányoznak a korrekt szerződéses kapcsolatok, amin sem a termelők sem a kereskedők nem akarnak változtatni. Mindkét fél a másikat hibáztatja, ha valamiért nem teljesült a szerződés. Az egymásra mutogatás mindig az áru piaci helyzetétől, kínálati vagy keresleti pozíciójától függ.

A tőkeszegénység miatt a kisebb tőkeerővel rendelkező termelők védtelenebbek a feketekereskedelem kihívásaival szemben is, mert az azonnali készpénzben történő fizetés a tagok egy része számára visszautasíthatatlanul vonzó ajánlatot jelent a TÉSZ-ek nyújtotta fizetési feltételekhez viszonyítva. A TÉSZ-ek esetében a feketegazdaság jelenléte sokkal jelentősebb anyagi és morális kockázatot jelent, mint az ágazat egészében, ugyanis a szervezetek szabálykövető magatartásukkal jelentős versenyhátrányt szenvednek el a szabályokat be nem tartókkal szemben. Ez nem teszi vonzóvá a TÉSZ-eket annak ellenére sem, hogy a tagsági jogviszony más előnyökkel is jár. A vizsgálat megmutatta, hogy a megkérdezettek pozitív diszkriminációt és a szabálysértőkkel szembeni jogi fellépés szigorítását várják a jogalkotóktól annak érdekében, hogy a szabályokat betartók ne kerüljenek versenyhátrányba a csalókkal szemben.

A TÉSZ, mint múködési forma, a mai magyar gazdasági viszonyok között jelenleg kevésbé versenyképes. Ennek oka a nevében is benne rejlik: termelő értékesítő szervezet (Rácz József Prémium Kert Kft., Mórakertész volt elnöke). Ezeket a szövetkezeteket általában a termelők irányítják, akiknek teljesen más az érdeke, mint egy értékesítő cégnek, aki a láncoknak értékesíti az árut. A termelő fő célja, hogy az őt 
képviselő szövetkezet a lehető legdrágábban adja el az áruját, az értékesítési szervezetnek viszont fedezetet kell képeznie a költségeire, rugalmasan tárgyalni, kedvezményeket adni a volumen után, stb. Ez egy skizofrén helyzetet szül. Ráadásul a feketekereskedelem és az áfa is sújtja a TÉSZ-eket, akik csak a munkaügyi és adózási szabályok, törvények maradéktalan betartásával tevékenykedhetnek. Nyugat Európában múködőképesebb modell a TÉSZ, de ott összefognak a kereskedőkkel, az életképes termelőket támogatják, a kevésbé versenyképes termelőket kiszervezik szociális szövetkezetekbe. Nálunk összekeveredett a piaci és a szociális gondolkodásmód.

Számos jó példa és sikeres üzem mellett is igaz, hogy a termelők zömének hiányosak a technológiai-, menedzsment- és marketingismeretei. Ragaszkodnak az elavult módszerekhez, változtatni, tanulni nemigen hajlandók. A versenyképes és hatékony mezőgazdasági termeléshez elengedhetetlen a humántőke megfelelő képzettsége, iskolázottsága, ugyanis a szakképzett, kvalifikált munkaerő számára a gazdálkodáshoz szükséges korszerű vállalkozói, piaci, marketing és technológiai ismeretek elsajátítása egyszerúbb, könnyebb.

A külföldi partnerek a megbízható és pontosan szállító vállalkozásokat részesítik előnybe még magasabb árak mellett is. Ezeket az előnyöket ki lehet használni és ki is használjuk. A gondot az jelenti, hogy még egy olcsóbb ajánlatról kiderül annak a minősége, a késedelmes vagy nem szállítás ténye, addig „áll” a piac és akár jelentős exportbevételektől is eleshetnek a szállítóképes vállalkozások. A megbízhatóságot, a szerződések maradéktalan és pontos teljesítését értékelik a vevők, a kérdés csak az, hogy ezt hogyan „árazzák" be.

4., Gond van minden egyes elöre jelzett mennyiséggel, legyen ez akár kisebb-, vagy nagyobb termésbecslés. Mindig kétkedve fogadom a január-februárban megjelenő termésbecsléseket, hisz ezeknek sajnos semmiféle reális alapjuk nincs, hisz „oly sokat éjszakázik" kint még a termék. A várható kevesebb termés előrejelzés esetén a termelői felvásárlási várakozások az „egekbe” szöknek és utána nagyon nehezen és sokszor túlkésőn szembesítik magukat a realitásokkal. Mire kiderül, hogy mégsem olyan rossz a termés, már megfordul a trend és egymás alá ígérve ajánlják az árut. $\mathrm{A}$ várható magas termés reményében, külföldön egy jóval alacsonyabb árat várnak az ajánlatoknál, mint az indokolt lenne. Utólag kiderül persze, hogy az előrejelzés túlzott volt, lásd a 2014-es meggy előrejelzést, a kereslet akkor kezdett élénkülni, amikor már nem volt megfelelő mennyiségú és minőségú alapanyag. Az egyik dunántúli meggybefőtt előállító konzervgyár akkor kezdett el 1200 tonna meggyet keresni, amikor kiderült, hogy a lengyel meggy sem minőségben, sem mennyiségben (kb. 30 \%-kal volt kevesebb az előre jelezettől) nem áll rendelkezésre. Ez a mennyiség, ha időben jelentkezik az igény, rendelkezésre állt és nem kellett volna légyártáshoz, jelentősen olcsóbban eladni. Nem tudni az indokát, hogy a várható elörejelzések milyen „érdekek” befolyása alatt történek. Az orosz embargó még tovább fokozza a „feszültséget”, bár a multinacionális cégek meg fogják találni a módját, hogy Európán kívüli vállalataik révén beszállítsanak az orosz piacra. Ezt az árkülönbözetet, árlépcsőt sajnos a magyar termelők fogják bevállalni.

Hasonló problémákkal kell szemben néznünk az idei évben az alma területén is. SzabolcsSzatmár megyében, ahol az alma termésmennyisége (elsősorban a lé minőségű) jelentősen több 2014-ben, mint az előző években volt. Ugyanakkor az ország más területein, de a dunántúli területen különösen, jóval kisebb termés betakarítására kerül sor. 2013-ban a dunántúli területről kb. 40 ezer tonna léalma került exportra, elsősorban Ausztriába, mely 2014-ben a 15 százalékát sem érte el az előző évinek. A multinacionális vállalatok (Rauch, Agrana) által kialakított 12 forintos beszállított magyarországi léalma árhoz viszonyítva, az osztrák gyáraik nem voltak hajlandóak a fuvarköltségből fakadó különbséget sem megfizetni, így „inkább” fél múszakkal dolgoztak. Az étkezési alma 
mennyisége viszont arányában megmaradt az előző évekének, kb. 18-20\%.

A bodza termését (vad és termesztett bodza) az előző évinél 20-30 százalékkal magasabbra prognosztizálták 2014-ben. Az árakat ennek megfelelően 20-30 százalékkal olcsóbbra kívánták tenni a külföldi vevők. Vad bodzából az előző évek 10 ezer tonnás felvásárlásával szemben, kb. 3500 tonna került felvásárlásra és a 7000 tonnás exporttal szemben, kb. 2000 tonna került külföldön értékesítésre. A nagyobb feldolgozók is jóval kevesebbet, csak a pillanatnyi igényt vásárolták meg. „Majd a termesztett bodzából pótoljuk" felkiáltással. A kedvezőtlen időjárás és a további kezdetben termelői, majd ehhez kapcsolódó ellentétes irányú vevői spekulációk miatt nem volt megfelelő minőségú és mennyiségú áru, mely exportra kerülhetett volna. A vevői „kivárásra” játszó spekulációk nem voltak megalapozottak, így október végére „kiürült" a fagyasztott bodza mennyisége Magyarországon. Az elmúlt években a fagyasztott bodza lehívások a következő év márciusban - májusban voltak. Már most elindultak a spekulációk a következő évi mennyiségek és árak tekintetében. A bodzára egyre növekszik az igény, de csak egy megfelelő árszintig. A világ bodzatermésének 18-20 százalékát Magyarország adja. Nincs még egy ilyen termékünk, amely ilyen arányt képviselne. Éppen ezért kellene e termék termesztésére, felvásárlására, értékesítésére és exportjára sokkal nagyobb figyelmet fordítani. Mindössze az utóbbi 3-4 évben „jegyezték" a statisztikákban a bodza felvásárlási és értékesítési mennyiségeit.

5., A zöldség-gyümölcságazat az összes mezőgazdasági ágazat közül rendre az egyik legnagyobb exportárbevételt produkálja azzal, hogy termelésének 50\%-át külföldön értékesíti. $\mathrm{Az}$ ágazatfejlesztéssel ezt az arányt Magyarország a jövőben is fenn kívánja tartani, sőt geopolitikai helyzeténél fogva az unió egy új zöldség-gyümölcs logisztikai centruma lehet. Ehhez viszont kedvezőbb adópolitikára és az őstermelői rendszer felülvizsgálatára, megszüntetésére lenne szükség. Több kormány indította már el az őstermelői rendszer felülvizsgálatát, csak vélhetően politikai okok miatt nem nyúltak a rendszerhez. Módosítottak rajta, próbálták szigorítani az adózás elkerülésének lehetőségét, csak sajnos kevés sikerrel. Ameddig az őstermelő nem kell, hogy blokkot, számlát, vagy egyéb bizonylatot, hogy adjon (törvény elóírja a nyugtaadási kötelezettséget, csak kevés az ellenőrzés, vagy "elnézik" azt az ellenőrök), addig nem követhető az adómentes adóalapja sem, hát még az adózott jövedelme. Az őstermelők hatféle, az egyéni vállalkozók háromféle adózási mód közül választhatnak, ami a termelésben a rövidtávon legkedvezőbb pénzügyi lehetőséget teszi legfontosabb szemponttá. Az őstermelők bevételhez viszonyított jövedelme az elmúlt 10 évben folyamatosan összességében 25\%-kal csökkent, mára csak a bevétel 3\%-át mutatják ki jövedelemként, ellentétben az egyéni vállalkozókkal, akiknek bevétel-jövedelem aránya megduplázódott és eléri a 7\%-ot, tehát kétszer olyan eredményesen termelnek. A gazdák $42 \%$-a a bevétel után nem mutat ki semmilyen jövedelmet, így adót még jelképesen sem fizet. $A z$ elmúlt évek tapasztalatai azt igazolják, hogy a magyar mezőgazdaságban a feketekereskedelem és az őstermelői forma szorosan összefonódik. Fontos azonban kiemelni, hogy az alapvető probléma nem az őstermelővel, mint adózási formával van, hanem a formához kapcsolódó adókedvezmények valódi jogosultságának nehézkes ellenőrizhetőségével. Az őstermelői forma más Európai Uniós országokban is van, csak ott mindenki fizet valamilyen szintü, általában általány adót.

6., A magyar zöldség- és gyümölcságazat stratégiai célkitúzése, hogy az Európai Unió következő, 2014-2020 közötti költségvetési ciklusának végére elérhető legyen az ágazatban a 3,5 millió tonnás termésmennyiség - közölte a Magyar Zöldség - Gyümölcs Szakmaközi Szervezet és Terméktanács (FruitVeB) elnöke Budapesten, egy szakmai rendezvényen (2014.01.20). A rendezvényen elhangzott termésmennyiség sajnos már az elmúlt néhány évben is felmerült. Feltételezhető, ha ezt a termésmennyiséget el tudná érni az ágazat, 
eladhatatlan zöldség-gyümölcs "hegyek” alakulnának ki. A termésmennyiséghez először meg kellene teremteni a "tényleges” felvevő piacot is. Az elnök úr elmondta, hogy a termelés ekkora felfutása mintegy 100 ezer új munkahely létrehozását jelentené a vidéken. A magyarországi zöldségfogyasztás növelésével, belső piacbővüléssel növelhető ennek az ágazatnak a szerepe és így a foglalkoztatás is. Úgy gondolom, itt lenne lehetőség a legolcsóbban és a leggyorsabban a foglalkoztatás növelésére.

Az új munkahelyek létrehozásához kedvezőbb adózási, egyszerübb (idénymunkánál) regisztrációs kötelezettséget kellene társítani. A jelenlegi szabályozás nem segíti elő a munkahelyteremtést még az idénymunkánál sem. Bármilyen kormányzati jó szándék ellenére sem megoldás a mai rendszer, hiszen előre be kell jelenteni az alkalmazottat, majd egy-két nap után „elfelejt” bemenni dolgozni, így a vállalkozás feleslegesen fizette be utána a járulékokat és kezdheti újra keresni a megfeleló munkaerőt. Ugyanakkor az ágazat fejlesztése érdekében vissza kellene szorítani a feketegazdaság arányát, ugyanis a szakértők szerint vannak, olyan területek az ágazatban ahol ez az arány eléri a 40-50 százalékot is. A munkahelyteremtést hátráltatja a közmunka program is, hisz az idénymunka jelentkezésekor a termelők, feldolgozók sem mennyiségben, sem minőségben nem találnak megfeleló munkaerőt. A közmunka adózásához, létesítéséhez hasonlóan meg lehetne szervezni a mezőgazdaság területén is az idénymunkát.

7., Szembe kell néznünk gyengébb exportteljesítményünkkel, amely alapvetően termelési, versenyképességi, minőségi, élelmiszerbiztonsági és marketing problémákra vezethető vissza, ugyanakkor számolnunk kell belső piacunkon a növekvő versennyel. Az olcsó, de silány minőségú áruk behozatalát a hazai beszállítók alkuerejének növelésével, a hazai hatósági minőségvizsgálati rendszer kiépítésével, a beszerzési ár alatti értékesítés megtiltásával (törvény van rá, napjainkban már egy-két esetet nyilvánosságra is hoznak), vagyis piacvédelemmel és a tisztességes verseny- helyzet megteremtésével lehetne féken tartani. Sajnos az Európai Unión belüli háromszögügylettel kijátszható és ezt $\mathrm{ki}$ is használják annak érdekében, hogy a beszerzési ár alatti értékesítésért ne kapjanak büntetést. $\mathrm{A}$ termelő eladja az áruházlánc külföldi áruházának, majd az már olcsóbban számlázza a magyar áruháznak, mely így nem követ el beszerzési ár alatti értékesítést. $\mathrm{Az}$ adó jogszabályok kizárják ezt a fajta tevékenységet, de ellenőrzésük, bizonyításuk nagyon nehéz. Véleményem szerint magas az ÁFA tartalom a zöldség-gyümölcs termékeknél. Viszont ez nem jelent versenyhátrányt a magyar termelők között, mivel az import termékek ÁFA tartalma a fogyasztói árban ugyan úgy $27 \%$, mint a magyar termékek esetében. Sajnos az import termékek esetében nagyobb az ÁFA-val történő „trükközés" lehetősége, mivel az import után ugyan abban az ÁFA bevallási időszakban bevallja és vissza is igényli az ÁFA-t, majd az értékesítésnél „elfelejti” bevallani és megfizetni azt. Ezzel jelentősen károsítja a költségvetést. Amennyiben kisebb lenne az ÁFA úgy kevesebb "hasznot" hozna, így már nem érné meg a büntetés veszélye miatt elcsalni az ÁFA-t.

A feketegazdaság csökkentésére a fordított áfa bevezetése, illetve a jelenlegi 27 százalékos áfa kulcs 5-10 százalékra történő mérséklésével lehetne hatást gyakorolni. Az áfa kulcs mérséklésére a gazdaság jelenlegi helyzetében kevés esélyt látok, a bevételi oldalon hiányt eredményezne.

A zöldség-gyümölcságazat nagy problémái közé tartozik az is, hogy a hazai termékek forgalmának mintegy harmadát, az import kétharmadát lebonyolító nagybani piacokon az egyes ügyletek jó 40 százaléka a feketekereskedelem körébe tartozik. Ez nem csupán a központi költségvetés számára jelent közvetlen bevételkiesést, de ellenőrizhetetlenné teszi az áruk származását és minőségét is.

Az áfacsalások miatt 4 adóforintból 1 biztosan nem folyik be a kincstárba. Két módszer kínálkozik az áfacsalások visszaszorítására. Az első az alapvető élelmiszerek áfa-jának drasztikus csökkentése, ám ha ez rövid időn 
belül nem lehetséges, úgy a fordított áfa fizetés módszerének gyors bevezetését javasolják. Körhintacsalás két módozata: exportmódszer: valamely társaság alapvető élelmiszert vásárol itthon, mégpedig azzal az állítólagos szándékkal, hogy az árut külföldön, az EU területén adják el. Az efféle ügyletek után nem kell itthon áfa-t fizetni. Az áru csak papíron lépi át a határt, hamis fuvarleveleket, külföldi számlákat állítanak elő, majd az áru fiktív iratok kíséretében Magyarországon talál gazdára.

Új uniós irányelvet fogadott el az Európai Unió Bizottsága a fordított adózás gyors reagálású bevezetéséről, amely 2013. augusztus 15-én lépet hatályba. Az irányelv szerint a tagállamok maguk dönthetnek arról, bevezetik-e a fordított áfát kilenc hónapra azoknál az élelmiszergazdasági termékeknél, amelyek nem jutnak el közvetlenül a fogyasztókhoz. A bevezetés az Európai Bizottság jóváhagyásához kötött, a testületnek pedig egy hónapon belül döntenie kell az ügyben. A gyors reagálású fordított adózást elvileg kilenc hónapnál tovább is alkalmazhatják a tagállamok, de ehhez már valamennyi EU-tagország beleegyezését meg kell szerezniük. Az irányelv 2018. december 31ig lesz hatályos.

A költségvetés számára pozitív hatást jelent a fordított adózás:

- Az áfacsalásokat visszaszorítja (hiszen a megfizetés és a levonás is ugyanannál az adóalanynál lesz). Így a fordított adózás megfelelő eszköz az áfacsalási módszerek visszaszorítására.

A kkv szektor részére is pozitív hatást jelent a fordított adózás:

- Mivel nem kell az áfa-t finanszírozniuk, azt az államtól visszaigényelniük, majd 45-135 napot várniuk a pénzükre. Azzal, hogy nem kellene a visszaigénylésnél ezt a hosszú időt kivárni, nagy segítséget kapnának a KKV-k a finanszírozási problémáik áthidalásához. Ugyanakkor lássuk be, hogy az állam ez idó alatt ebből a pénzből is finanszírozza magát.

A költségvetésnek a fordított adózás átmeneti likviditási gondot jelent a következő mértékben:

- Likviditási elónyt jelent a vevőnek, emiatt azonban a bevezetés évében a költségvetés számára a befizetések eltolódnak és egyszeri pénzforgalmi áfabevétel-kiesés jelentkezik. Ennek mértéke a zömében havi és negyedéves bevallási gyakoriságot figyelembe véve 1,5-2 havi, adott ügylettípusból származó áfa bevételnek felelhet meg. Ezért sem lehetne a fordított ÁFA fizetést valamennyi érintett terméknél egy időben bevezetni.

Paradox helyzet, hogy az egyik oldalról jövedelemadózási szemlélettel, átláthatatlan adózási kategóriákba sorolva a feketegazdaságot erősítve, jövedelmük eltitkolására sarkaljuk a termelőinket, ami ellen a törvény szigorával, kommandós csapatokat küldve „próbálunk harcolni”, a másik oldalról pedig tudomásul véve a feketegazdaság vidéki „jövedelemtermelő és népességtartó képességét", a rendszer kereteit inkább mégsem bolygatjuk. A piacgazdaság bevezetése óta alapvetően egyik kormány, sem mert a kialakult rendszerhez hozzányúlni, így például az idejét múlt őstermelői rendszerhez sem.

$\mathrm{Az}$ adócsalások csak egy része adódik az áfa visszaélésekből a zöldség-gyümölcs ágazatban, mely éves szinten a szakmaközi szervezetek becslése szerint eléri a 46 milliárd forintot. Jelentős adócsalások adódnak, jelenleg „legálisan” az őstermelők adózási lehetőségéből is.

Az Európai Unió egyes régi tagországaiban az egyéni gazdálkodóikra hasonló szabályozási szisztémát alakítottak ki (csökkentett adminisztrációs kötelezettség, kedvezményes, többnyire átalányadózás). De ott - ellentétben a magyar szabályozással - mindenki fizet adót, bármilyen alacsony is az árbevétele. További fontos különbség, hogy nincsenek jogi és adózási különbségek a termelők között. Olyan tevékenységeket, melyek egyéni vállalkozóként és őstermelőként is végezhetők, nem lehet ugyanazon személynek egyidejűleg mindkét formában végeznie. Magyarországon a jogi „kiskapuk" ezt a lehetőséget megteremtik.

8., A gyakorlati tapasztalataimat, a zöldséggyümölcs külkereskedelemben dolgozó vállalatvezetőkkel, érdekképviseleti vezetőkkel való jó kapcsolatomat kihasználva tettem fel kérdéseket egy-egy beszélgetés alkalmával az adórendszer átalakítására illetve a 
feketekereskedelem visszaszorítására beruházásaikat, tevékenységüket, vonatkozóan. A kérdések megoldásának ellenőrizhetőségüket a törvényi előírások szükségességében illetve az adott válaszokkal mellett végzik. Ezzel szemben a sötét oldal egyet értettünk. A megoldásokban már az érdekek különbségéből fakadóan voltak nézetkülönbségek.

$\mathrm{Az}$ őstermelő gazdák általában adót sem fizetnek. A mezőgazdaságban tevékenykedő jogi személyiségú cégek (állami gazdaságok, termelőszövetkezetek, Rt-k, Kft-k) fizetnek, de a gazdák általában nem. Igaz a gazdák egy része felvetette, hogy igen nagy adót fizetnek. Az ÁFA-t! Csakhogy mindenki tudja, aki csak egy kicsit is járatos az adók ügyében, hogy az ÁFA-t nem a gazda fizeti! És nem is az iparvállalat, meg nem is a kereskedelem. Az ÁFA-t a fogyasztó fizeti! A vállalatok ebben csak közvetítő szerepet játszanak. Az általuk beszerzett anyagok és eszközök után fizetett ÁFA-t visszaigénylik, a termék eladásakor az ÁFA-t a fogyasztóval megfizettetik és ezt, az államnak továbbítják, átutalják.

A fordított adózás csak rövidtávon kezeli az áfacsalást, ugyanis a csalók vagy más termékköre térnek át, vagy más államban próbálkoznak. A fordított adózás célja inkább az, hogy alkalmazása idején érdemi változások történjenek, többek közt az ellenőrzés hatékonyságának javításában, illetve egyéb, egyszerű eszközök alkalmazásával, akár a szabályozás alakításával.

A regisztrál nagykereskedelmi vállalkozások (2008-as EU irányelv szerint Magyarországon is regisztrációhoz van kötve a zöldség-gyümölcs nagykereskedelmi tevékenység) a nepperközvetítői, ahol gyakorlatilag nincs beruházás, ennek megfelelően nincs amortizáció, nincs telephely, nincs infrastruktúra, nincs legális foglalkoztatás, nincs minőségbiztosítás, gyakorlatilag csak papíron kereskednek, vagy fizetnek, vagy nem, és aztán szezon végén bedöntik a céget, eltûnnek áfástól együtt. Hová túnik az a 27 százalék áfa, ami gyakorlatilag a duplája egy átlagos évben elvárható adózott eredménynek? Ez elég forrást nyújt ahhoz, hogy a termelőknek többet ígérjenek, tehát elvonják, az árut a legális kereskedelem elöl. Így van elég pénz arra, hogy a nagykereskedelem felé olcsóbban ajánlják be az árut, ezáltal megint csak a TÉSZ-eknek, tehát a legális kereskedelemnek állítsanak konkurenciát, és még így is marad elég pénz a zsebükben.

A zöldség-gyümölcs ágazatra fordított éves 100 millió forintos marketing költségvetés nem elfogadható. Nagyobb vállalatok egy-egy termékre magasabb marketing költségekkel számolnak. Így a zöldség-gyümölcs fogyasztás népszerűsítése nem megfelelő, pedig a termelés növeléséhez a fogyasztást kell először növelni. Jól megszervezett marketing stratégiára és elkülönített marketig alapra van szüksége az ágazatnak ahhoz, hogy a jelenlegi 181 kg/fö/év zöldség-gyümölcsfogyasztásunkat, - mely az élelmiszerfogyasztás 30 \%-a -, növelni tudjuk.

\section{FELHASZNÁLT IRODALOM:}

[1] Az élelmiszergazdaság külkereskedelme 2013. január-decemberi időszak XVII. évfolyam, 3. szám (2014)

[2] Falkné D. Bánó Klára (2006): Interkulturális útmutató nemzetközi cégek és projektek vezetői és tagjai számára. EU Working Papers. Budapesti Gazdasági Főiskola Külkereskedelmi Főiskolai Karának szakmai folyóirata. IX. écf. 1. szám.

[3] FruitVeb évértékelők 2012-2013

[4] KSH Mezőgazdasági adatok

[5] Lakner Zoltán - Sass Pál (1997): A zöldség és gyümölcs versenyképessége. Mezőgazdasági Szaktudás Kiadó. Bp. ISBN 963356 207-4

[6] Magyar zöldség-gyümölcs ágazati stratégia, 2013. augusztus 29. (FruitVeb) 